\author{
A. Kramarenko, \\ Doctor of Philosophy in Economics, Senior Lecturer of tne Department of Management and \\ Administration of the Educational and Scientific Institute "Karazin Business School", V. N. Karazin \\ Kharkiv National University, Kharkiv \\ ORCID ID: 0000-0001-5987-1247
}

DOI: $10.32702 / 2306-6814.2021 .2 .23$

\title{
INCLUSIVE FORMAT OF CREATIVE INDUSTRIES FOR SOCIAL BUSINESS
}

\author{
А. О. Крамаренко, \\ к. е. н., старший викладач кафедри управління та адміністрування ННІ "Каразінська школа бізнесу", \\ Харківський національний університет імені В. Н. Каразіна, м. Харків
}

\section{ІНКАЮЗИВНИЙ ФОРМАТ КРЕАТИВНИХ ІНАУСТРІЙ ААЯ СОЦІААЬНОГО БІЗНЕСУ}

The article examines the concept of "social inclusion" as a process which ensures gain the opportunities to participate fully in economic, social, political and cultural life. The problems of such social inclusive groups as persons with disabilities, persons released from places of deprivation of liberty, participants of ATO/UFO, women in difficult circumstances, homeless persons, elderly persons, children and youth, residents of rural areas are systematized in the following areas: economic, socio-psychological, professional, legal, medical. It was shown that the main economic problems for the majority of inclusive groups are low income, difficulties with employment. The consequence is crime, health problems, various forms of addiction, lack of communication and social adaptation.

The concept of "creative industries" as sectors whose activities are based on cultural values, or other artistic individual or collective creative expressions is considered. The possibilities of creative business areas (advertising, architecture, crafts, design, fashion, video, film and photography, games, music, publishing and printing activities, computers, research and development) to solve the problem of social exclusion are analyzed. It was revealed that for involvement in most types of economic activity, a qualification at the level of upper secondary education, post-secondary nontertiary education is sufficient. As a result, a significant number of socially inclusive groups can be included in the production of economic and public goods.

Based on the study of the most common social business models, it was shown that a partial solution to the problems of social inclusive groups, such as low incomes and employment problems, is possible on the basis of creative industries using such common social business models as employment model, fee-for-service model, service subsidy model, cooperative model, low-income client as market model, organizational support model. At the same time, the financialself-sufficiencyof enterprises is ensured mainly due to income from the sale of products and services.

У рамках статті вивчено поняття "соціальної інклюзії" як процесу, що забезпечує отримання можливостей для повноцінної участі в економічному, соціальному, політичному і культурному житті. Систематизовано проблеми таких соціальних інклюзивних груп, як інваліди; особи, звільнені з місць позбавлення волі; учасники АТО/ООС; жінки у складних життєвих обставинах, бездомні особи; літні особи; діти та молодь; жителі сільської місцевості за такими напрямами: економічні, соціально-психологічні, професійні, правові, медичні. Показано, що основними 
економічними проблемамидля більшості інклюзивних груп є низький рівень доходів, проблеми з працевлаштуванням. Наслідком є злочинність, проблеми зі здоров'ям, різні форми залежності, брак спілкування та соціальної адаптації.

Розглянуто концепцію "креативних індустрій" як сектори, діяльність яких заснована на культурних цінностях або інших художніх індивідуальних або колективних творчих виразах. Проаналізовано можливості сфер креативного бізнесу (реклама, архітектура, ремесла, дизайн, мода, відео, кіно і фотографія, ігри, музика, видавнича і поліграфічна діяльність, комп'ютери, дослідження і розробки) для вирішення проблеми соціальної ексклюзії. Виявлено, щодля залучення до більшості видів економічної діяльності достатньоює кваліфікація на рівні старша середня освіта, післяшкільна невища освіта. В результаті значна кількість соціальних інклюзивних груп може бути включена у виробництво економічних і суспільних благ.

На основі вивчення найбільш поширених моделей соціального бізнесу показано, що часткове вирішення проблем соціальних інклюзивних груп, як-от: проблеми низьких доходів і зайнятості, можливо на основі креативних індустрій з використанням таких загальних соціальних бізнес-моделей, як модель зайнятості, модель плати за послуги, модель субсидування послуг, кооперативна модель, модель ринку з низьким доходом клієнта, модель організаційної підтримки. Водночас забезпечується фінансова самодостатність підприємств переважно за рахунок доходів від продажу продуктів і послуг.

Key words: social inclusion, sustainable development, creative business, social enterprise, stakeholders

Ключові слова: соціальна інклюзія, сталий розъиток, креатиВний бізнес, соціальне підприємство, стейкхолдери.

\section{INTRODUCTION}

Due to The Copenhagen Declaration and Programme of Action, a key outcome of the 1995 World Summit for Social Development, building inclusive societies is a longstanding commitment of the international community and a major component of the quest for a new humanism. Inclusive society is based on fundamental values of equity, equality, social justice, and human rights and freedoms, as well as on the principles of tolerance and embracing diversity [1]. UNESCO is particularly concerned by the issue of human rights, discrimination, gender equality, poverty eradication, democracy, sciences and social transformations, including urbanization and migration. The organization has prioritized working on social inclusion policies, for three groups of potentially disadvantaged people: migrants, persons with disabilities, and indigenous minorities, with a focus on youth [2].

Almost 106 thousand children, or $1.5 \%$ of the total child population of the country (Ukraine), live and are brought up in boarding schools. Every three days, 250 children are admitted to boarding schools mainly because of poverty and the inability to provide the necessary services for the child. At least 600 thousand children live in dysfunctional families [3]. Thus, the problems of the international community are also relevant for Ukraine. In this regard, this study is devoted to the study of inclusive opportunities of Ukrainian society.

International Trade Centre reports that the creative industries sector accounts for $7 \%$ of the world's GDP, growing at an annual rate of $8.7 \%$ [4]. The development of the creative industries sector is not only an engine to increase the share of developing countries in world trade, but can also directly benefit poor communities by generating income, creating jobs and empowering artists and people.
As Ukraine is among the top-25 countries in the category "Most awarded countries" in the Global Creativity Report 2019 by Cannes Lions [5]. The most developed subsectors of the creative industries are advertising, IT sector, media, design, and handicraft. The fashion industry has been evolving and expanding for many years and has the potential for growth [6]. Based on this creative industries are considered as an effective tool for increasing social inclusive. This statement needs more deep investigation, which is performed in the article.

\section{LITERATURE REVIEW}

Creative industries are increasingly acknowledged worldwide for having enormous potential as engines driving economic and social development [7]. Not only do they account for higher than average growth rate and job creation, but they are also channels of cultural identity which play a key role in promoting cultural diversity. An interesting issue for detailed consideration is the

Table 1. Definition of "social inclusion"

\begin{tabular}{|l|l|}
\hline \multicolumn{1}{|c|}{ Source } & \multicolumn{1}{c|}{ Definition } \\
\hline UNESCO & $\begin{array}{l}\text { Social rights bring together numerous rights that must be dealt } \\
\text { with at the local level: rights to housing, education, clean water } \\
\text { and health care emphasize the role of local authorities as a } \\
\text { welfare provider and social provision as a duty which lies within } \\
\text { city halls and councils [9] }\end{array}$ \\
\hline UNEVOC & $\begin{array}{l}\text { The conditions and processes whereby an individual or a } \\
\text { population group is granted access to benefits or beneficial } \\
\text { circumstances, including those related to education and training } \\
{[10] .}\end{array}$ \\
\hline $\begin{array}{l}\text { World Bank } \\
\text { the European } \\
\text { Communities }\end{array}$ & $\begin{array}{l}\text { The process of improving the ability, opportunity, and dignity of } \\
\text { people, disadvantaged on the basis of their identity, to take part in } \\
\text { society [11]. }\end{array}$ \\
$\begin{array}{l}\text { The process which ensures that at risk of poverty and social } \\
\text { exclusion gain the opportunities and resources necessary to } \\
\text { participate fully in economic, social, political and cultural life } \\
\text { and to enjoy a standard of living that is considered normal in the } \\
\text { society [12]. }\end{array}$ \\
\hline
\end{tabular}

Source: built by the author based on [9-12]. 
Table 2. Bank of problems of inclusive social groups

\begin{tabular}{|c|c|c|c|c|c|}
\hline $\begin{array}{c}\text { Type } \\
\text { of problems } \\
\begin{array}{c}\text { Inclusive social } \\
\text { group }\end{array} \\
\end{array}$ & Economic & $\begin{array}{c}\text { Social and } \\
\text { psychological } \\
\text { problems }\end{array}$ & Professional & Legal & Medical \\
\hline $\begin{array}{l}\text { Persons with } \\
\text { disabilities }\end{array}$ & $\begin{array}{l}\text { low income; } \\
\text { lack of special jobs, } \\
\text { acceptable working } \\
\text { conditions }\end{array}$ & $\begin{array}{l}\text { lack of material, } \\
\text { technical, } \\
\text { information, } \\
\text { methodological } \\
\text { support }\end{array}$ & $\begin{array}{l}\text { lack of vocational } \\
\text { training facilities } \\
\text { and opportunities } \\
\text { for continuing } \\
\text { education }\end{array}$ & & $\begin{array}{l}\text { insufficient } \\
\text { quantity and } \\
\text { quality of } \\
\text { affordable } \\
\text { treatment } \\
\text { services } \\
\end{array}$ \\
\hline $\begin{array}{l}\text { Persons released } \\
\text { from places of } \\
\text { deprivation of } \\
\text { liberty }\end{array}$ & & $\begin{array}{l}\text { difficulties in } \\
\text { communicating with } \\
\text { other people }\end{array}$ & $\begin{array}{l}\text { lack of proper } \\
\text { professional } \\
\text { qualifications }\end{array}$ & $\begin{array}{l}\text { lack of basic identity } \\
\text { documents; lack of } \\
\text { awareness of their } \\
\text { rights/responsibilities }\end{array}$ & $\begin{array}{l}\text { needs for the } \\
\text { treatment of } \\
\text { various somatic } \\
\text { and infectious } \\
\text { diseases }\end{array}$ \\
\hline $\begin{array}{l}\text { Participants of } \\
\text { the anti-terrorist } \\
\text { operation } \\
\text { (ATO) / united } \\
\text { forces operation } \\
\text { (UFO) }\end{array}$ & & $\begin{array}{l}\text { social adaptation is } \\
\text { difficult }\end{array}$ & need for retraining & & $\begin{array}{l}\text { psychological } \\
\text { and physical } \\
\text { rehabilitation }\end{array}$ \\
\hline $\begin{array}{l}\text { Women in } \\
\text { difficult } \\
\text { circumstances }\end{array}$ & \begin{tabular}{|l|} 
inability to \\
independently \\
provide living \\
conditions \\
\end{tabular} & $\begin{array}{l}\text { low self-esteem, } \\
\text { self-doubt, } \\
\text { dependence on men }\end{array}$ & $\begin{array}{l}\text { limited } \\
\text { opportunities for } \\
\text { professional } \\
\text { qualification } \\
\end{array}$ & & \\
\hline $\begin{array}{l}\text { Homeless } \\
\text { persons }\end{array}$ & $\begin{array}{l}\text { lack of adequate } \\
\text { housing }\end{array}$ & $\begin{array}{l}\text { social adaptation is } \\
\text { difficult }\end{array}$ & $\begin{array}{l}\text { limited } \\
\text { opportunities for } \\
\text { professional } \\
\text { qualification }\end{array}$ & $\begin{array}{l}\text { lack of awareness of } \\
\text { rights and } \\
\text { opportunities }\end{array}$ & $\begin{array}{l}\text { limited access to } \\
\text { health facilities }\end{array}$ \\
\hline Elderly persons & low income level & $\begin{array}{l}\text { narrowing the scope } \\
\text { of communication, } \\
\text { exclusion from } \\
\text { society }\end{array}$ & $\begin{array}{l}\text { restriction of vital } \\
\text { activity }\end{array}$ & & $\begin{array}{l}\text { lack of } \\
\text { affordable } \\
\text { essential health } \\
\text { services }\end{array}$ \\
\hline $\begin{array}{l}\text { Children and } \\
\text { youth }\end{array}$ & $\begin{array}{l}\text { lack of information } \\
\text { about the nature of } \\
\text { labor relations, } \\
\text { unemployment }\end{array}$ & $\begin{array}{l}\text { child crime; low } \\
\text { level of readiness for } \\
\text { independent life; bad } \\
\text { habits and addiction }\end{array}$ & $\begin{array}{l}\text { limited } \\
\text { opportunities for } \\
\text { professional } \\
\text { qualification }\end{array}$ & & \\
\hline $\begin{array}{l}\text { Residents of } \\
\text { rural areas }\end{array}$ & $\begin{array}{l}\text { lack of access to } \\
\text { basic infrastructure, } \\
\text { low income, } \\
\text { unemployment }\end{array}$ & & \begin{tabular}{|l} 
limited \\
opportunities for \\
professional \\
qualification \\
\end{tabular} & & \\
\hline
\end{tabular}

Source: built by the author based on [3].

combination of trends in social inclusive development and for such social groups as persons with disabilities; persons breakthrough opportunities of creative industries. For released from prison; participants in the anti-terrorist Ukrainian realities, the issue is further actualized by the widespread social exclusion.

Social exclusion refers to the multiple and changing factors resulting in people being excluded from the normal exchanges, practices and rights of modern society [8]. One of the most obvious factors is poverty, but social exclusion also refers to inadequate rights in housing, education, health and access to services. These problems are acute

\section{Table 3. The concept of "creative industries"}

\begin{tabular}{|l|l|}
\hline \multicolumn{1}{|c|}{ Source } & \multicolumn{1}{c|}{ Definition } \\
\hline $\begin{array}{l}\text { Cambridge } \\
\text { Dictionary }\end{array}$ & $\begin{array}{l}\text { Industries that are based on work in } \\
\text { which original ideas are important, such as work in the arts or } \\
\text { the media, in designing computer software, etc [13] }\end{array}$ \\
\hline $\begin{array}{l}\text { International } \\
\text { Trade Centre }\end{array}$ & $\begin{array}{l}\text { Creative industries uses an individual's creativity, skill and } \\
\text { talent for job and wealth creation through the generation and } \\
\text { exploitation of intellectual property [4] }\end{array}$ \\
\hline Deloitte & $\begin{array}{l}\text { Industries that use culture as an input and have a cultural } \\
\text { dimension, although their outputs are mainly functional. They } \\
\text { include architecture and design, which integrate creative } \\
\text { elements into wider processes, as well as sub-sectors such as } \\
\text { graphic design, fashion design, or advertising [14] }\end{array}$ \\
\hline $\begin{array}{l}\text { Commission of } \\
\text { the European } \\
\text { Communities }\end{array}$ & $\begin{array}{l}\text { Cultural and creative sectors are comprised of all sectors } \\
\text { whose activities are based on cultural values, or other artistic } \\
\text { individual or collective creative expressions [8] }\end{array}$ \\
\hline
\end{tabular}

Source: built by the author based on $[4 ; 8 ; 13 ; 14]$. operation; women who have fallen into difficult life circumstances; homeless people; elderly people; children and youth; residents of rural areas.

An inclusive society should also be equipped with appropriate mechanisms that enable all its citizens to participate in the decision-making processes that affect their lives, and ultimately shape their common future [1]. Thus, the question of models and forms of realization of creative industries' opportunities for solving the problems of the main inclusive groups of the population requires detailed consideration.

\section{PURPOSE OF ARTICLE}

The purpose of the article is to study the main problems of social inclusive groups of the population, as well as the possibilities of solving these problems on the basis of creative industries and social business models.

\section{RESULTS}

To study the problem, the main approaches to the definition of "social inclusion" were studied. The results are presented in table 1 . 
Table 4. Inclusive opportunities of creative industries

\begin{tabular}{|c|c|c|c|c|}
\hline $\begin{array}{c}\text { Business } \\
\text { area }\end{array}$ & Types of business & $\begin{array}{c}\text { Minimal ISCED level of } \\
\text { education needed }\end{array}$ & $\begin{array}{c}\text { Inclusive groups of } \\
\text { stakeholders }\end{array}$ & $\begin{array}{c}\text { The key problems } \\
\text { solutions }\end{array}$ \\
\hline Advertising & $\begin{array}{l}\text { marketing research, } \\
\text { advertising communications } \\
\text { planning, production of } \\
\text { advertising materials, } \\
\text { public relations campaigns }\end{array}$ & $\begin{array}{l}\text { Upper secondary } \\
\text { education; } \\
\text { Post-secondary non- } \\
\text { tertiary education; } \\
\text { Short-cycle tertiary } \\
\text { education; } \\
\text { Bachelor's level } \\
\end{array}$ & $\begin{array}{l}\text { Persons with disabilities; } \\
\text { Women in difficult } \\
\text { circumstances; } \\
\text { Children and youth; } \\
\text { Residents of rural areas }\end{array}$ & $\begin{array}{l}\text { low incomes; } \\
\text { difficulty of employment; } \\
\text { low self-esteem; child } \\
\text { crime; internet addiction }\end{array}$ \\
\hline Architecture & $\begin{array}{l}\text { planning of construction } \\
\text { costs, preservation of } \\
\text { heritage buildings, } \\
\text { engineering consulting }\end{array}$ & $\begin{array}{l}\text { Bachelor's level; } \\
\text { Master's level }\end{array}$ & $\begin{array}{l}\text { Persons with disabilities; } \\
\text { Women in difficult } \\
\text { circumstances; Elderly } \\
\text { persons }\end{array}$ & $\begin{array}{l}\text { low incomes; difficulty of } \\
\text { employment; low self- } \\
\text { esteem; social exclusion }\end{array}$ \\
\hline $\begin{array}{l}\text { The market } \\
\text { for artistic } \\
\text { goods }\end{array}$ & $\begin{array}{l}\text { trade in original, unique and } \\
\text { rare goods of high artistic } \\
\text { and aesthetic value through } \\
\text { auctions, galleries, shops, } \\
\text { supermarkets and the } \\
\text { Internet }\end{array}$ & $\begin{array}{l}\text { Short-cycle tertiary } \\
\text { education; } \\
\text { Bachelor's level }\end{array}$ & $\begin{array}{l}\text { Persons with disabilities; } \\
\text { Children and youth; Elderly } \\
\text { persons }\end{array}$ & $\begin{array}{l}\text { low incomes; difficulty of } \\
\text { employment; social } \\
\text { exclusion; child crime }\end{array}$ \\
\hline Crafts & $\begin{array}{l}\text { manufacture of handmade } \\
\text { products }\end{array}$ & $\begin{array}{l}\text { Lower secondary } \\
\text { education; } \\
\text { Upper secondary } \\
\text { education; } \\
\text { Post-secondary non- } \\
\text { tertiary education }\end{array}$ & $\begin{array}{l}\text { Persons with disabilities; } \\
\text { Persons released from places } \\
\text { of deprivation of liberty; } \\
\text { Participants of ATO / UFO; } \\
\text { Homeless persons; } \\
\text { Children and youth; } \\
\text { Residents of rural areas }\end{array}$ & $\begin{array}{l}\text { low incomes; difficulty of } \\
\text { employment; lack of } \\
\text { professional qualifications }\end{array}$ \\
\hline Design & $\begin{array}{l}\text { creation of graphic design, } \\
\text { interior design, industrial } \\
\text { design, packaging } \\
\text { production }\end{array}$ & $\begin{array}{l}\text { Upper secondary } \\
\text { education; } \\
\text { Post-secondary non- } \\
\text { tertiary education; } \\
\text { Short-cycle tertiary } \\
\text { education; } \\
\text { Bachelor's level } \\
\end{array}$ & $\begin{array}{l}\text { Persons with disabilities; } \\
\text { Persons released from places } \\
\text { of deprivation of liberty; } \\
\text { Women in difficult } \\
\text { circumstances; } \\
\text { Children and youth; } \\
\text { Residents of rural areas } \\
\end{array}$ & $\begin{array}{l}\text { low incomes; difficulty of } \\
\text { employment; difficulties in } \\
\text { communicating with other } \\
\text { people; low self-esteem; } \\
\text { child crime; internet } \\
\text { addiction }\end{array}$ \\
\hline Fashion & $\begin{array}{l}\text { design of clothing, shoes } \\
\text { and fashion accessories, } \\
\text { fashion advice, distribution } \\
\text { of fashion products }\end{array}$ & $\begin{array}{l}\text { Lower secondary } \\
\text { education; } \\
\text { Upper secondary } \\
\text { education; } \\
\text { Post-secondary non- } \\
\text { tertiary education; } \\
\text { Short-cycle tertiary } \\
\text { education } \\
\end{array}$ & $\begin{array}{l}\text { Persons with disabilities; } \\
\text { Women in difficult } \\
\text { circumstances; } \\
\text { Children and youth }\end{array}$ & $\begin{array}{l}\text { low incomes; difficulty of } \\
\text { employment; low self- } \\
\text { esteem; child crime; } \\
\text { internet addiction }\end{array}$ \\
\hline $\begin{array}{l}\text { Video, film } \\
\text { and } \\
\text { photography }\end{array}$ & $\begin{array}{l}\text { video and photo production } \\
\text { services }\end{array}$ & $\begin{array}{l}\text { Lower secondary } \\
\text { education; } \\
\text { Upper secondary } \\
\text { education; } \\
\text { Post-secondary non- } \\
\text { tertiary education; } \\
\text { Short-cycle tertiary } \\
\text { education } \\
\end{array}$ & $\begin{array}{l}\text { Persons with disabilities; } \\
\text { Persons released from places } \\
\text { of deprivation of liberty; } \\
\text { Participants of ATO / UFO; } \\
\text { Women in difficult } \\
\text { circumstances; } \\
\text { Children and youth; } \\
\text { Residents of rural areas } \\
\end{array}$ & $\begin{array}{l}\text { low incomes; difficulty of } \\
\text { employment; lack of } \\
\text { professional qualifications; } \\
\text { difficulties in } \\
\text { communicating with other } \\
\text { people; social adaptation; } \\
\text { low self-esteem; child } \\
\text { crime; internet addiction } \\
\end{array}$ \\
\hline Games & $\begin{array}{l}\text { creation and distribution of } \\
\text { computer games }\end{array}$ & $\begin{array}{l}\text { Upper secondary } \\
\text { education; } \\
\text { Post-secondary non- } \\
\text { tertiary education; } \\
\text { Short-cycle tertiary } \\
\text { education; } \\
\text { Bachelor's level } \\
\end{array}$ & $\begin{array}{l}\text { Persons with disabilities; } \\
\text { Children and youth }\end{array}$ & $\begin{array}{l}\text { low incomes; difficulty of } \\
\text { employment; child crime; } \\
\text { internet addiction }\end{array}$ \\
\hline Music & $\begin{array}{l}\text { creation, musical } \\
\text { performance, reproduction } \\
\text { and distribution of sound } \\
\text { recordings }\end{array}$ & $\begin{array}{l}\text { Upper secondary } \\
\text { education; } \\
\text { Post-secondary non- } \\
\text { tertiary education; } \\
\text { Short-cycle tertiary } \\
\text { education }\end{array}$ & $\begin{array}{l}\text { Persons with disabilities; } \\
\text { Persons released from places } \\
\text { of deprivation of liberty; } \\
\text { Participants of ATO / UFO; } \\
\text { Children and youth; } \\
\text { Residents of rural areas }\end{array}$ & $\begin{array}{l}\text { difficulty of employment; } \\
\text { lack of professional } \\
\text { qualifications; difficulties } \\
\text { in communicating with } \\
\text { other people; social } \\
\text { adaptation; internet } \\
\text { addiction }\end{array}$ \\
\hline $\begin{array}{l}\text { Publishing } \\
\text { and printing } \\
\text { activities }\end{array}$ & $\begin{array}{l}\text { writing content and } \\
\text { publishing books, } \\
\text { magazines, and digital } \\
\text { content }\end{array}$ & $\begin{array}{l}\text { Upper secondary } \\
\text { education; } \\
\text { Post-secondary non- } \\
\text { tertiary education; } \\
\text { Short-cycle tertiary } \\
\text { education; } \\
\text { Bachelor's level } \\
\end{array}$ & $\begin{array}{l}\text { Persons with disabilities; } \\
\text { Women in difficult } \\
\text { circumstances; } \\
\text { Children and youth; Elderly } \\
\text { persons }\end{array}$ & $\begin{array}{l}\text { difficulty of employment; } \\
\text { low self-esteem; social } \\
\text { exclusion; child crime; } \\
\text { internet addiction }\end{array}$ \\
\hline Computers & $\begin{array}{l}\text { computer services, software } \\
\text { development, system } \\
\text { integration, system design } \\
\text { and analysis }\end{array}$ & $\begin{array}{l}\text { Post-secondary non- } \\
\text { tertiary education; } \\
\text { Short-cycle tertiary } \\
\text { education; } \\
\text { Bachelor's level; } \\
\text { Master's level } \\
\end{array}$ & $\begin{array}{l}\text { Persons with disabilities; } \\
\text { Children and youth }\end{array}$ & $\begin{array}{l}\text { low incomes; difficulty of } \\
\text { employment; child crime; } \\
\text { internet addiction }\end{array}$ \\
\hline $\begin{array}{l}\text { Research and } \\
\text { development }\end{array}$ & $\begin{array}{l}\text { scientific and technical } \\
\text { developments to improve } \\
\text { products and create new } \\
\text { products, new processes, } \\
\text { new methods and } \\
\text { technologies that can meet } \\
\text { the needs of the market } \\
\end{array}$ & $\begin{array}{l}\text { Bachelor's level; } \\
\text { Master's level; } \\
\text { Doctoral level }\end{array}$ & $\begin{array}{l}\text { Persons with disabilities; } \\
\text { Elderly persons }\end{array}$ & $\begin{array}{l}\text { low incomes; difficulty of } \\
\text { employment; social } \\
\text { exclusion }\end{array}$ \\
\hline
\end{tabular}

Source: built by the author based on $[3 ; 15-20]$. 
Table 5. Social business models

\begin{tabular}{|c|c|c|c|c|c|}
\hline \multirow{2}{*}{ Model } & \multirow{2}{*}{ Impact } & \multirow{2}{*}{\begin{tabular}{|c|} 
Key \\
stakeholders \\
\end{tabular}} & \multicolumn{2}{|c|}{ Finance } & \multirow{2}{*}{ Samples } \\
\hline & & & Revenues & Expenditures & \\
\hline $\begin{array}{l}\text { EMPLOYMENT } \\
\text { MODEL }\end{array}$ & $\begin{array}{l}\text { employment and training of social } \\
\text { inclusive groups; } \\
\text { social adaptation and support } \\
\text { (vocational training, mental health } \\
\text { counseling, temporary housing) }\end{array}$ & \begin{tabular}{|l|} 
women in crisis \\
situations, former \\
addicts, homeless \\
persons
\end{tabular} & $\begin{array}{l}\text { selling } \\
\text { manufactured } \\
\text { products and } \\
\text { services }\end{array}$ & $\begin{array}{l}\text { operating costs; } \\
\text { additional social } \\
\text { costs due to the } \\
\text { hiring of workers } \\
\text { from social } \\
\text { inclusive groups } \\
\end{array}$ & $\begin{array}{l}\text { shop, a cafe, a bakery, } \\
\text { a woodworking } \\
\text { business }\end{array}$ \\
\hline $\begin{array}{l}\text { FEE-FOR-SERVICE } \\
\text { MODEL }\end{array}$ & $\begin{array}{l}\text { commercializing social services and } \\
\text { selling them either directly to social } \\
\text { inclusive groups or to third-party } \\
\text { payers }\end{array}$ & $\begin{array}{l}\text { social inclusive } \\
\text { groups }\end{array}$ & $\begin{array}{l}\text { payment for } \\
\text { products and } \\
\text { services, which } \\
\text { covers their cost }\end{array}$ & $\begin{array}{l}\text { operating } \\
\text { expenses; } \\
\text { subsidies of } \\
\text { social programs } \\
\text { that do not have } \\
\text { a business } \\
\text { component }\end{array}$ & $\begin{array}{l}\text { organizations in } \\
\text { which membership } \\
\text { dues, trade } \\
\text { associations }\end{array}$ \\
\hline $\begin{array}{l}\text { MARKET } \\
\text { INTERMEDIARY } \\
\text { MODEL }\end{array}$ & $\begin{array}{l}\text { providing services (product } \\
\text { development, production and } \\
\text { marketing assistance, lending) to } \\
\text { small producers to open them access } \\
\text { to markets and increase the value of } \\
\text { their products; the market } \\
\text { intermediary buys products that } \\
\text { customers produce, and then sells the } \\
\text { products in retail markets at the } \\
\text { expense of a surcharge }\end{array}$ & $\begin{array}{l}\text { small and } \\
\text { medium business }\end{array}$ & $\begin{array}{l}\text { selling client } \\
\text { products }\end{array}$ & $\begin{array}{l}\text { operating } \\
\text { expenses, } \\
\text { payment of } \\
\text { services } \\
\text { developers of } \\
\text { services } \\
\text { marketing and } \\
\text { credit services }\end{array}$ & $\begin{array}{l}\text { agriculture, handicraft } \\
\text { and marketing }\end{array}$ \\
\hline $\begin{array}{l}\text { ENTREPRENEUR } \\
\text { SUPPORT MODEL }\end{array}$ & $\begin{array}{l}\text { providing business support services } \\
\text { to firms and private entrepreneurs }\end{array}$ & $\begin{array}{l}\text { small and } \\
\text { medium business }\end{array}$ & $\begin{array}{l}\text { selling services to } \\
\text { clients }\end{array}$ & $\begin{array}{l}\text { operating } \\
\text { expenses of the } \\
\text { business }\end{array}$ & $\begin{array}{l}\text { financial institutions, } \\
\text { consulting agencies, } \\
\text { companies providing } \\
\text { professional services } \\
\text { (accounting, legal, } \\
\text { and market } \\
\text { information) }\end{array}$ \\
\hline $\begin{array}{l}\text { SERVICE } \\
\text { SUBSIDIZATION } \\
\text { MODEL }\end{array}$ & redistributing income from activities & $\begin{array}{l}\text { social inclusive } \\
\text { groups; territorial } \\
\text { communities }\end{array}$ & $\begin{array}{l}\text { selling products } \\
\text { or services }\end{array}$ & \begin{tabular}{|l} 
operating \\
expenses, \\
financing of \\
social programs
\end{tabular} & any business \\
\hline $\begin{array}{l}\text { COOPERATIVE } \\
\text { MODEL }\end{array}$ & $\begin{array}{l}\text { providing services to members of the } \\
\text { cooperative (market research, } \\
\text { technical assistance, collective } \\
\text { bargaining and lobbying, providing } \\
\text { access to products and services, } \\
\text { access to external markets) }\end{array}$ & $\begin{array}{l}\text { small producers } \\
\text { of the same } \\
\text { product group, } \\
\text { the community of } \\
\text { people with } \\
\text { common needs } \\
\text { (access to capital, } \\
\text { health) }\end{array}$ & $\begin{array}{l}\text { sale of goods and } \\
\text { services to } \\
\text { members or } \\
\text { external } \\
\text { customers in } \\
\text { commercial } \\
\text { markets }\end{array}$ & $\begin{array}{l}\text { operating } \\
\text { expenses, } \\
\text { payment of the } \\
\text { received services } \\
\text { and products }\end{array}$ & $\begin{array}{l}\text { agricultural } \\
\text { cooperatives, credit } \\
\text { unions }\end{array}$ \\
\hline $\begin{array}{l}\text { LOW-INCOME } \\
\text { CLIENT AS } \\
\text { MARKET MODEL }\end{array}$ & $\begin{array}{l}\text { providing access to products and } \\
\text { services to individuals who are able } \\
\text { to meet only their basic needs, } \\
\text { improving customer health, } \\
\text { education, quality of life and } \\
\text { personal opportunities }\end{array}$ & $\begin{array}{l}\text { people with low } \\
\text { income }\end{array}$ & $\begin{array}{l}\text { selling products } \\
\text { or services }\end{array}$ & $\begin{array}{l}\text { operating } \\
\text { expenses, } \\
\text { marketing costs }\end{array}$ & any business \\
\hline $\begin{array}{l}\text { MARKET LINKAGE } \\
\text { MODEL }\end{array}$ & $\begin{array}{l}\text { organizing business relationships } \\
\text { between buyers and manufacturers }\end{array}$ & $\begin{array}{l}\text { small producers, } \\
\text { local firms and } \\
\text { cooperatives }\end{array}$ & $\begin{array}{l}\text { payment for } \\
\text { intermediary } \\
\text { services }\end{array}$ & $\begin{array}{l}\text { marketing } \\
\text { research, event } \\
\text { organization }\end{array}$ & $\begin{array}{l}\text { commercial, } \\
\text { industrial, financial } \\
\text { broker }\end{array}$ \\
\hline $\begin{array}{l}\text { ORGANIZATIONAL } \\
\text { SUPPORT MODEL }\end{array}$ & $\begin{array}{l}\text { financing a program that has a social } \\
\text { impact }\end{array}$ & $\begin{array}{l}\text { social inclusive } \\
\text { groups; territorial } \\
\text { communities }\end{array}$ & $\begin{array}{l}\text { sale of goods and } \\
\text { services to } \\
\text { members or } \\
\text { external } \\
\text { customers in } \\
\text { commercial } \\
\text { markets }\end{array}$ & $\begin{array}{l}\text { operating } \\
\text { expenses of the } \\
\text { main activity; } \\
\text { expenses of the } \\
\text { social program } \\
\text { and operating } \\
\text { expenses of the } \\
\text { non-profit parent } \\
\text { organization }\end{array}$ & any business \\
\hline
\end{tabular}

Source: built by the author based on [22].

Thus, social inclusion means equal access to different public goods for different groups of the population. The problem of social exclusion is the lack or insufficient provision of opportunities to include as many people as possible in the production process. In order to understand what human resources can be further involved in economic turnover, the main problems of inclusive social groups were analyzed and systematized. The results are summarized in table 2 .
According to table 2, the problems that affect almost all inclusive groups are low income, employment and ensuring the necessary level of well-being. The solution to these and related problems lies in increasing the level of involvement of social groups in the process of creating economic and public goods. The purpose of the article is to study the possibilities of creative industries to solve the described problems. For this purpose, the essence of the category "creative 
industries" was studied. The results are presented in table 3.

Based on the definition of the concept, a complex of creative industries, including specific types of economic activities, was systematized in the course of further research. A comparison of the types of activities and the minimum level of education required for inclusion in the corresponding type of activity is carried out. On the basis of the criterion of the level of education, the distribution of inclusive groups of stakeholders between different spheres of creative industries was completed. This distribution also allowed us to identify key problems that can be solved on the basis of the corresponding type of activity within the creative industries. The results are presented in table 4.

Based on the data in table 4, for most of the presented activities within the creative industries, upper secondary education, post-secondary non-tertiary education is sufficient. This creates opportunities to attract a significant number of representatives of social inclusive groups. At the same time, there is a potential to reduce the severity of such problems as low incomes, difficulties with employment, and social adaptation. The development of the social orientation of creative industries is possible in the format of a social business model.

According to social investment Programmes WNISEF4, social enterprises are those employing more than $50 \%$ of workers belonging to social inclusive groups, and a large part of the profit is reinvested in the company's development to create new jobs; working less than $50 \%$ of workers belonging to social inclusive groups, and at least $10 \%$ of the profit goes to a social purpose; at least $20 \%$ of the profit goes to social purpose [21]. To study the prospects of applying creative business models to involve inclusive groups, the main models of social enterprises used in Ukraine were studied. The results of the analysis are systematized in table 5.

Thus, for the involvement of social inclusive groups based on creative industries using social business models employment model, fee-for-service model, service subsidization model, cooperative model, low-income client as market model, organizational support model can be achieved.

\section{CONCLUSIONS}

The issues of social inclusion, the main inclusive groups and their current problems, and particularly the scope of creative business, creative industries opportunities in creating social impact were studied in the article. Based on the materials considered, the following conclusions were made:

1) Social inclusion is associated not only with limited access to public goods, but also with exclusion from the production of products and services.

2) The main social inclusive groups of Ukraine, whose representatives for objective reasons are limited in the possibilities of inclusion in the economic processes, are persons with disabilities, persons released from places of deprivation of liberty, participants of ATO/UFO, women in difficult circumstances, homeless persons, elderly persons, children and youth, residents of rural areas.

3) Provide a partial solution to the problems of social inclusive groups, such as low incomes and employment problems, possibly on the basis of creative industries using such common social business models as employment model, fee-for-service model, service subsidy model, cooperative model, low-income client as market model, organizational support model.

\section{References:}

1. UNESCO (2020), "Social Inclusion, Social Transformations, Social Innovation". URL: http://www.unesco.org/new/fileadmin/MULTIMEDIA/HQ/BPI/EPA/ images/media_services/Director-General/ConceptNoteSociallnclusionSocialTransformations SociallnnovationEN.pdf (accessed 17.01.2021).

2. UNESCO (2020), "Social inclusion and social change". URL: https://en.unesco.org/indigenous-peoples/social (accessed 17.01.2021).

3. (2020), Банк проблем та моделей соціальних підприємств для їх вирішення. URL: https://drive.google.com/file/d/10k_zkvlld-T8SwDgdoNACKHRb5ALG67J/view (accessed 17.01.2021).

4. International Trade Centre (2020), "Creative Industries". URL: https://www.intracen.org/itc/sectors/ creative-industries / (accessed 17.01.2021).

5. Cannes Lions (2020), "Global Creativity Report 2019". URL: https://www.canneslions.com/2019-globalcreativity-report (accessed 17.01.2021).

6. Ukraine Invest (2020), "Creative Industries". URL: https://ukraineinvest.gov.ua/industries/creativeindustries / (accessed 17.01.2021).

7. European Commission (2020), "Cultural and creative sectors". URL: https://ec.europa.eu/culture/sectors / cultural-and-creative-sectors (accessed 17.01.2021).

8. Omtzigt, J.-D. (2009), "Survey on Social inclusion: Theory and Policy". URL: https://ec.europa.eu/regional_policy/archive/policy/future/pdf/1_omtzigt_final_formatted.pdf (accessed 17.01.2021).

9. UNESCO (2020), "Social and Human Sciences". URL: http://www.unesco.org/new/en/social-andhuman-sciences/themes/urban-development/migrantsinclusion-in-cities/good-practices/social-inclusion / (accessed 17.01.2021).

10. UNESCO-UNEVOC (2020), "Inclusion". URL: https://unevoc.unesco.org/home/TVETipedia+Glossary $/$ filt=all $/$ id=449 (accessed 17.01.2021).

11. World Bank (2020), "Social Inclusion". URL: https://www.worldbank.org/en/topic/social-inclusion (accessed 17.01.2021).

12. United Nations (2020), "Identifying social inclusion and exclusion". URL: https://www.un.org/esa/socdev / rwss/2016/chapter1.pdf (accessed 17.01.2021).

13. Cambridge Dictionary (2020), "Creative Industry". URL: https://dictionary.cambridge.org/dictionary / english / creative-industry (accessed 17.01.2021).

14. Deloitte (2020), "Cultural and Creative Sectors". URL: https://www2.deloitte.com/content/dam/Deloitte/co/Documents/finance/ArtFinance $\% 20-\% 20$ Creative \%20industries \% 20-\%20version \%20v6.pdf (accessed 17.01.2021).

15. McQuilten, G. Warr, D. Humphery, K. and Spiers, A. (2020), "Ambivalent entrepreneurs: arts-based social enterprise in a neoliberal world", Social Enterprise Journal, no. 2 , pp. $121-140$. 
16. Petrova, P. (2019), "Cultural entrepreneurship illustrated on the non-profit arts sector in the Czech republic", Central European Business Review, no. 2, pp. 56-74.

17. Toscher B., Dahle Y. and Steinert M. (2020), "Get Give Make Live. An empirical comparative study of motivations for technology, youth and arts entrepreneurship", Social Enterprise Journal, no. 2, pp. 179-202.

18. Carter, M. and Carter, C. (2020), "The Creative Business Model Canvas", Social Enterprise Journal, no. 2, pp. $141-158$.

19. UNESCO Institute for Statistics (2013), "Fields of education and training 2013 (ISCED-F 2013) - Detailed field descriptions". URL: http://uis.unesco.org/sites/default/ files/documents/international-standard-classification-ofeducation-fields-of-education-and-training-2013-detailedfield-descriptions-2015-en.pdf (accessed 17.01.2021).

20. UNESCO Institute for Statistics (2011), "International Standard Classification of Education ISCED 2011". URL: http://uis.unesco.org/sites/default/files/ documents / international-standard-classification-ofeducation-isced-2011-en.pdf (accessed 17.01.2021).

21. (2020), Розвиток соціального підприємництва в Україні. Біла книга. URL: https://drive.google.com/ file/d/1Th4nskvSkcLEpZmKg0b6BztOZCLBI_5S/view (accessed 17.01.2021).

22. (2020), Соціальне підприємництво в Україні. Зелена книга. URL: https://drive.google.com/file/d/ 1yfrAPFZ2fB66i7hAgEkn_WVK3jAaDTd4/view (accessed 17.01.2021).

\section{References:}

1. UNESCO (2012), "Social Inclusion, Social Transformations, Social Innovation", available at: http:/ /www.unesco.org/new/fileadmin/MULTIMEDIA/HQ/ $\mathrm{BPI} / \mathrm{EPA} /$ images/media services/Director-General/ ConceptNoteSociallnclusionSocialTransformationsSociallnnovationEN.pdf (Accessed 17 January 2021).

2. UNESCO (2020), "Social inclusion and social change", available at: https://en.unesco.org/indigenouspeoples /social (Accessed 17 January 2021).

3. Social business IN UA (2018), "Bank problem ta modelej sotsial'nykh pidpryiemstv dlia ikh vyrishennia", available at: https://drive.google.com/file/d/10k zkvlld-T8SwDgdoNACKHRb5ALG67J/view (Accessed $\overline{17}$ January 2021).

4. International Trade Centre (2020), "Creative Industries", available at: https://www.intracen.org/itc/ sectors /creative-industries / (Accessed 17 January 2021).

5. Cannes Lions (2020), "Global Creativity Report 2019", available at: https://www.canneslions.com/2019global-creativity-report (Accessed 17 January 2021).

6. Ukraine Invest (2020), "Creative Industries", available at: https://ukraineinvest.gov.ua/industries/ creative-industries / (Accessed 17 January 2021).

7. European Commission (2020), "Cultural and creative sectors", available at: https://ec.europa.eu /culture / sectors/cultural-and-creative-sectors (Accessed 17 January 2021).

8. Omtzigt, J.-D. (2009), "Survey on Social inclusion: Theory and Policy", available at: https://ec.europa.eu/ regional_policy/archive/policy/future/pdf /1 omtzigt_final_formatted.pdf (Accessed 17 January 2021).
9. UNESCO (2020), "Social and Human Sciences", available at: http://www.unesco.org/new/en/socialand-human-sciences/themes/urban-development / migrants-inclusion-in-cities/good-practices/socialinclusion / (Accessed 17 January 2021).

10. UNESCO-UNEVOC (2020), "Inclusion", available at: https://unevoc.unesco.org/home/TVETipedia+Glossary $/$ filt=all $/$ id=449 (Accessed 17 January 2021).

11. World Bank (2020), "Social Inclusion", available at: https://www.worldbank.org/en/topic/social-inclusion (Accessed 17 January 2021).

12. United Nations (2016), "Identifying social inclusion and exclusion", available at: https: / /www.un.org/esa / socdev/rwss/2016/chapter1.pdf (Accessed 17 January 2021).

13. Cambridge Dictionary (2020), "Creative Industry", available at: https://dictionary.cambridge.org/dictionary/english/creative-industry (Accessed 17 January 2021).

14. Deloitte (2019), "Cultural and Creative Sectors", available at: https://www2.deloitte.com/content/dam/ Deloitte/co/Documents/finance /ArtFinance \% 20$\% 20$ Creative $\% 20$ industries $\% 20-\% 20$ version $\% 20 v 6 . p d f$ (Accessed 17 January 2021).

15. McQuilten, G. Warr, D. Humphery, K. and Spiers, A. (2020), "Ambivalent entrepreneurs: arts-based social enterprise in a neoliberal world", Social Enterprise Journal, vol. 2, pp. $121-140$.

16. Petrova, P. (2019), "Cultural entrepreneurship illustrated on the non-profit arts sector in the Czech republic", Central European Business Review, vol. 2, pp. $56-74$.

17. Toscher, B. Dahle, Y. and Steinert, M. (2020), "Get Give Make Live. An empirical comparative study of motivations for technology, youth and arts entrepreneurship", Social Enterprise Journal, vol. 2, pp. 179-202.

18. Carter, M. and Carter, C. (2020), "The Creative Business Model Canvas", Social Enterprise Journal, vol. 2, pp. 141-158.

19. UNESCO Institute for Statistics (2013), "Fields of education and training 2013 (ISCED-F 2013) - Detailed field descriptions", available at: http://uis.unesco.org/ sites/default/files/documents/international-standardclassification-of-education-fields-of-education-andtraining-2013-detailed-field-descriptions-2015-en.pdf (Accessed 17 January 2021).

20. UNESCO Institute for Statistics (2011), "International Standard Classification of Education ISCED 2011", available at: http://uis.unesco.org/sites/ default/files/documents/international-standardclassification-of-education-isced-2011-en.pdf (Accessed 17 January 2021).

21. Kokot', V. Reheliuk, S. and Bocharnikova A. (2020), "Development of social entrepreneurship in Ukraine. White book", available at: https://drive.google.com/file/d/ 1Th4nskvSkcLEpZmKg0b6BztOZCLBI_5S/view (Accessed 17 January 2021).

22. Kokot', V. (2020), "Social entrepreneurship in Ukraine. Green book", available at: https://drive.google.com/file/d/1yfrAPFZ2fB66i7hAgEkn_WVK3jAaDTd4/view (Accessed 17 January 2021).

Стаття надійшла до редакиї 18.01.2021 p. 